\title{
Expression of the insulin-like growth factors and their receptors in adenocarcinoma of the colon
}

\author{
S Freier, O Weiss, M Eran, A Flyvbjerg, R Dahan, I Nephesh, T Safra, E Shiloni, I Raz
}

Laboratory of Mucosal Immunology, Shaare Zedek Medical Center, Jerusalem, Israel S Freier

M Eran

Department of Oncology, Shaare Zedek Medical Center T Safra

Departments of Internal Medicine and Surgery, Hadassah

Medical Centre, Jerusalem, Israel $\mathrm{O}$ Weiss

R Dahan

I Nephesh

E Shiloni

I Raz

Institute of Experimental Clinical Research, Aarhus Kommunehospital, Aarhus, Denmark A Flyvbjerg

Correspondence to: Professor S Freier, Laboratory of Mucosal Immunology, Shaare Zedek Medical Centre, Jerusalem 91031, Israel.

Accepted for publication 4 November 1998

\begin{abstract}
Aims-To study changes in the expression of insulin-like growth factors (IGFs) and their receptors, as well as production of the IGF-I and IGF-II polypeptides, in adenocarcinoma of the colon.

Methods-Malignant tissue obtained at operation was used. Total RNA was extracted and specific IGF-I and IGF-II and their receptor mRNAs were measured by a solution hybridisation RNase protection assay. IGF-I and IGF-II polypeptides were measured by specific immunoassays.

Results-All normal tissues expressed IGF-II, IGF-I receptor, and IGF-II/ mannose-6-phosphate (Man-6-P) receptor. IGF-I mRNA could not be detected but the polypeptide was present in small but equal amounts in normal and malignant tissue. IGF-II was expressed 40 times more abundantly in colonic tumours than in adjacent normal tissue and the concentration of the corresponding polypeptide was twice as high in the malignant tissue. IGF-I receptor expression was increased by a factor of 2.5 and IGF-II/Man-6-P receptor by a factor of 4 .
\end{abstract}

Conclusions-This study confirms that in adenocarcinoma of the human colon there is increased expression of IGF-I receptor and IGF-II. Furthermore, IGF-II/Man6-P receptor message is increased and the increase in IGF-II message is accompanied by a doubling of the IGF-II protein in the tumour tissue compared with the adjacent normal tissue. These findings suggest that the IGF-II/Man-6-P receptor may also be involved in development of adenocarcinoma of the colon. There is rapidly accumulating evidence implicating the IGF system in the development of malignancy of the large bowel.

(Gut 1999;44:704-708)

Keywords: insulin-like growth factors; adenocarcinoma; colon

Cancer of the colon is one of the most common types of cancer in humans. So far, it has not been possible to devise effective medical treatment against it. As intestinal growth throughout life is under the control of various growth factors, an understanding of their possible role in this neoplasm may be essential to planning effective treatment. These growth factors are both endocrine products and locally produced peptides with paracrine and autocrine effects. The factors known to stimulate intestinal growth include epidermal growth factor, gas- trin, cholecystokinin, insulin-like growth factors I and II (IGF-I and -II), growth hormone, enteroglucagon, neurotensin, and peptide YY. ${ }^{12}$

IGF-I and -II play an important role in the growth, normal and abnormal, of many tissues in the human body. In order to exert their effect they bind to specific cell surface receptors. Furthermore, the IGFs are bound in the serum to one of six binding proteins. Biological functions attributed to these binding proteins include regulation of the stability and clearance of the IGFs, acting as shuttles for IGF transport, and modulating IGF action at the cellular level. ${ }^{3}$

IGFs are expressed in the normal intestine in both the fetus and the adult. ${ }^{4}$ After intestinal resection in the experimental animal, IGF-II receptors are increased in the villous and crypt regions of the jejunum and ileum at 12 hours, providing circumstantial evidence for the role of IGF-II during phases of regeneration of the intestine. ${ }^{5}$ Recent work has suggested that IGF-II also plays a role in human colorectal cancer. A certain proportion of colorectal cancers contain increased IGF-II message, ${ }^{46}$ and adenocarcinoma cell lines also produce IGF-II protein. ${ }^{78}$ IGF-I receptor is increased in several colon cancer cell lines and in colorectal cancer tissue obtained at operation..$^{9} 10$ The IGF-II/ Man-6-P receptor has been found in malignant colorectal cell lines, ${ }^{10}{ }^{11}$ but it has not so far been shown that the expression of this receptor is higher in colorectal cancer than in normal colonic tissue. Nor has it been shown that IGF-II protein is increased in colorectal cancer. We studied the expression of IGF-I and -II and their two receptors in tissue obtained at operation for resection of adenocarcinoma of the colon. Furthermore, we measured IGF-I and IGF-II polypeptide in cancerous and normal adjacent bowel.

\section{Methods}

GROUPS OF INDIVIDUALS

IGF gene expression was studied in six patients with carcinoma of the colon, two men and four women, whose ages ranged from 46 to 82 years. In three, the carcinoma was in the sigmoid colon, in two near the splenic flexure, and in one in the ascending colon near the hepatic flexure. Two patients had metastases in the liver: a 46 year old woman had a mucinous adenocarcinoma near the hepatic flexure; a 56 year old man had a moderately differentiated adenocarcinoma in the sigmoid.

Abbreviations used in this paper: IGF, insulin-like growth factor; Man-6-P, mannose-6-phosphate. 
In addition, IGF gene expression was studied in biopsy specimens from three patients with malignant polyps and in ten normal biopsy samples obtained from individuals undergoing colonoscopy for diagnostic purposes.

In another group of 10 patients, carcinomatous and normal adjacent tissue obtained at operation was kept for estimation of IGF-I and IGF-II protein.

PREPARATION OF TISSUES

Tissues were obtained during resection of the bowel for adenocarcinoma. Tumour tissue and normal tissue adjacent to the tumour were removed and thoroughly rinsed in isotonic saline to avoid contamination by serum. These were placed on ice within a few minutes of removal, and appropriate tissues were selected by the pathologist and placed in RPMI 1640 . Ulcerated and necrotic areas were avoided. Within 15 minutes of removal, the tissues were rapidly frozen in liquid nitrogen and subse-

A

Bases
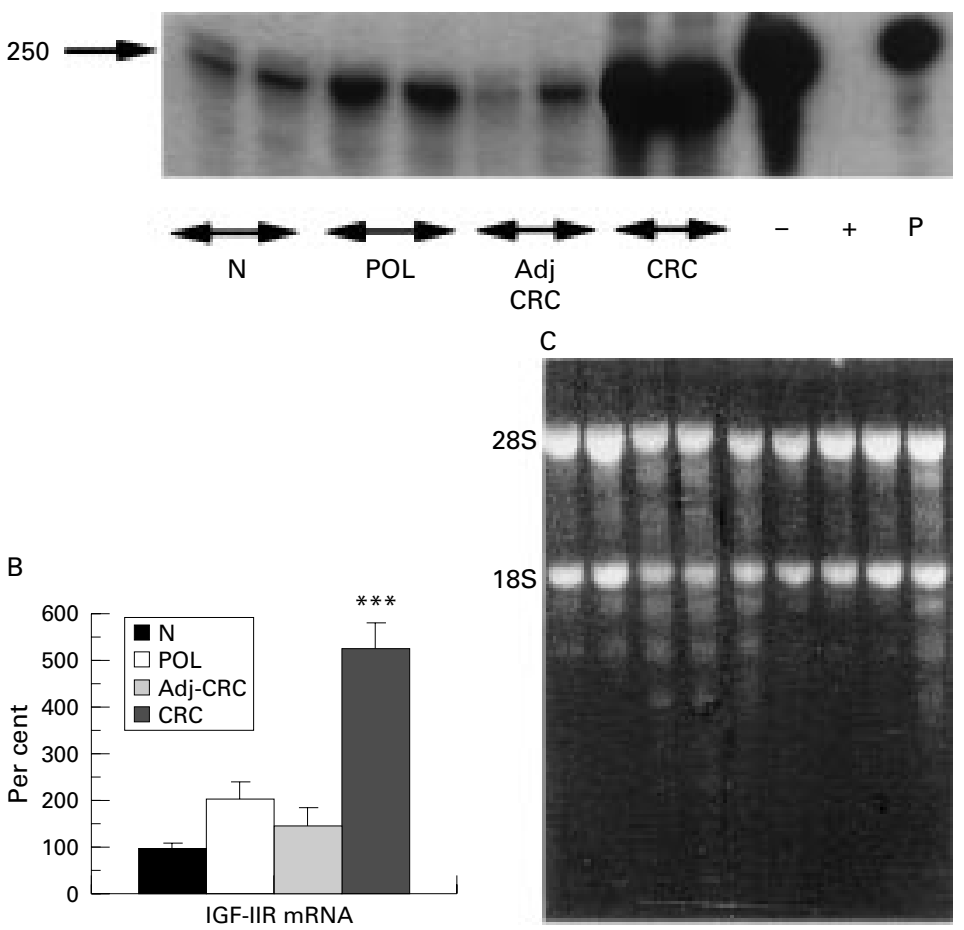

B

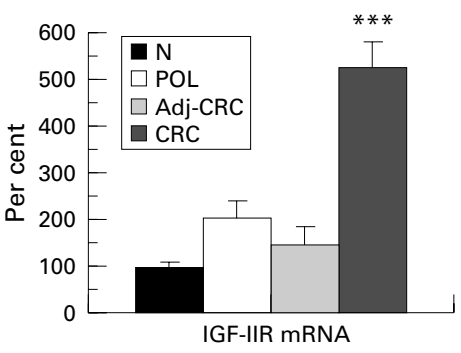

$$
18 \mathrm{~S}
$$

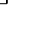

quently preserved at $-70^{\circ} \mathrm{C}$ until used for preparation of total RNA. Tissues from normal healthy individuals and from patients with malignant polyps were obtained during routine colonoscopy of persons at risk for colorectal tumour. The remainder of the tissue was placed in formalin and underwent formal histological evaluation and staging by Dukes' classification.

This project was approved by the ethical committee of the Shaare Zedek Hospital, and written permission was obtained for removal of the biopsy material.

GENE EXPRESSION OF IGF-I, IGF-I RECEPTOR, IGF-II, AND IGF-II RECEPTOR

Tissue mRNA for IGF-I, IGF-II, and their receptors was analysed by an RNase protection assay as follows. Total RNA was prepared from the tissues by the method of Chomczynski and Sacchi ${ }^{12}$ and quantified by measuring absorbance at $260 \mathrm{~nm}$. The integrity of the RNA and the accuracy of the spectrophotometric determinations were assessed by visual inspection of the ethidium bromide stained $28 \mathrm{~S}$ and $18 \mathrm{~S}$ ribosomal RNA bands after agarose gel electrophoresis. The IGF-I, IGF-II, IGF-I receptor, and IGF-II/Man-6-P receptor riboprobes were a gift from Dr Derek LeRoith, NIH, Bethesda, MD, USA.

The riboprobe for human IGF-I was a 442 bp Pst I/RsaI fragment of a human IGF-I cDNA subcloned into plasmid vector pGEM-3. When this construct was linearised with HindIII, a protected band of 420 bases was obtained. ${ }^{13}$ The riboprobe for human IGF-II was a $556 \mathrm{bp}$ PstI/AccI fragment of human IGF-II cDNA subcloned into plasmid vector pGEM-3. For generation of antisense RNAs, this construct was linearised with HindIII, and, using T7 RNA polymerase, a 603 base transcript containing 251 bases of the 5' untranslated region and 283 bases of the coding region was generated. ${ }^{14}$ The riboprobe for human IGF-I receptor was a 379 bp EcoRI/XhoI fragment coding for part of the $\alpha$-subunit of the human IGF-I receptor subcloned into plasmid vector pGEM-3. After linearisation of this construct with HindIII, an antisense riboprobe was generated with T7 RNA polymerase. The final riboprobe contained 32 bases of pGEM-3 plasmid sequence and 379 bases complementary to IGF-I receptor mRNA. ${ }^{15}$ A human IGF-II/Man-6-P receptor riboprobe was generated by subcloning a $500 \mathrm{bp}$ EcoRI/HindIII fragment of the corresponding cDNA into pGEM-2. After linearisation of this construct with EcoRI, an antisense riboprobe containing 250 bases complementary to IGF-II/Man-6-P receptor mRNA and 10 bases of pGEM-2 sequence was generated with T7 RNA polymerase. $^{13}$

Solution hybridisation RNase protection assays were performed as follows. A $20 \mu \mathrm{g}$ sample of total RNA was hybridised with $1 \times 10^{6}$ dpm ${ }^{32} \mathrm{P}$-labelled antisense RNA probes. The hybridisation was carried out at $45^{\circ} \mathrm{C}$ for 16 hours in a buffer containing $80 \%$ formamide. After hybridisation, RNA samples were digested with RNase $\mathrm{A}$, and $\mathrm{T} 1$ and the

the same six individuals (CRC). There was a highly significant difference between adenocarcinoma of the colon and the other groups $\left(\star_{*}^{*} p<0.001\right) . m R N A$ levels were measured by solution hybridisation RNase protection assay as described in Methods. The values are the relative density of the bands as a percentage of the normal tissue. Results are mean (SEM). (C) The integrity of the RNA from these individuals was assessed by visual inspection of ethidium bromide stained $28 S$ and $18 S$ ribosomal bands after agarose ge electrophoresis of $10 \mu \mathrm{g}$ aliquots. 


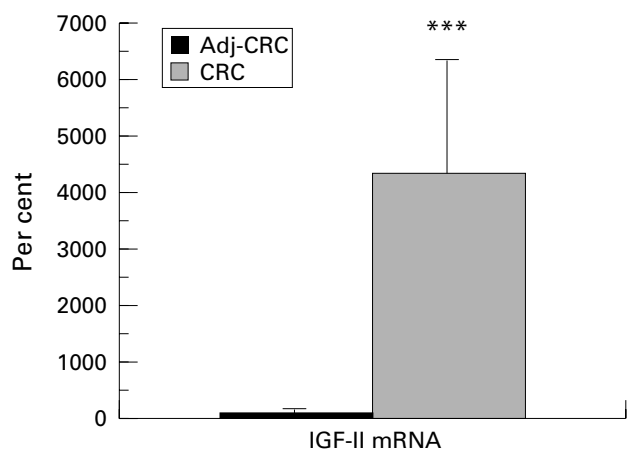

Figure 2 Expression of insulin-like growth factor-II (IGF-II) mRNA in adenocarcinoma of the colon (CRC) compared with that in tissue adjacent to the carcinoma (Adj-CRC). mRNA levels were measured by solution hybridisation RNase protection assay as described in Methods. The values are the relative density of the bands as percentage of the normal adjacent tissue coming from six individuals and specimens of adenocarcinoma obtained from the same individuals. There was a highly significant difference $\left({ }^{* *} p<0.001\right)$ between the two groups. Results are mean (SEM).

protected hybrids were extracted with phenol/ chloroform, ethanol precipitated, and electrophoresed on $8 \%$ polyacrylamide/8 M urea denaturing gel. Multiple autoradiograms from each gel were scanned by a densitometer connected to an Apple Macintosh computer.

TISSUE IGF-I AND -II EXTRACTION AND

IMMUNOASSAYS

For the extraction of IGF-I, about $100 \mathrm{mg}$ tissue was homogenised on ice in $1 \mathrm{~mol} / 1$ acetic acid ( $5 \mathrm{mg} / \mathrm{g}$ tissue) with an UltraTurrax TD 25 and further disrupted using a Potter Elvehjelm homogeniser. ${ }^{16}{ }^{17}$ The tissues were extracted twice and after lyophilization were redissolved in $40 \mathrm{mmol} / \mathrm{l}$ phosphate buffer $(\mathrm{pH}$ 8). IGF-II was extracted by homogenising about $100 \mathrm{mg}$ tissue on ice in $3.3 \mathrm{~mol} / 1$ formic $\mathrm{acid} / 0.5 \%$ Tween $20(5 \mathrm{ml} / \mathrm{g}$ tissue $)$ and centrifuged at $40000 \mathrm{~g}$ for 10 minutes at $4^{\circ} \mathrm{C} .{ }^{18} \mathrm{~A}$ $150 \mu \mathrm{l}$ aliquot of the supernatant was transferred into a second set of tubes and placed in a water bath at $90^{\circ} \mathrm{C}$ for 30 minutes. The tubes

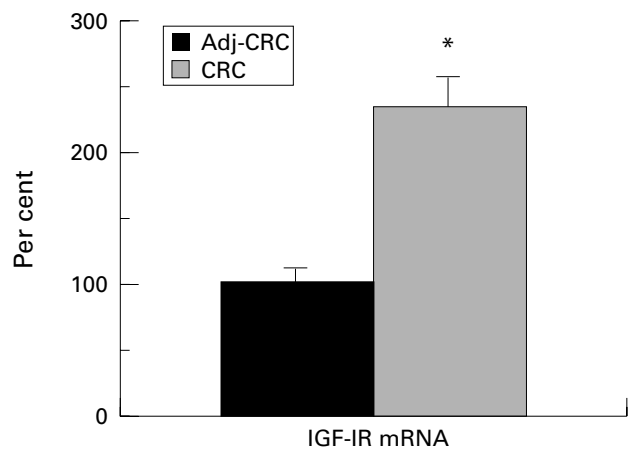

Figure 3 Expression of insulin-like growth factor-I receptor (IGF-IR) $m R N A$ in adenocarcinoma of the colon (CRC) compared with that in tissue adjacent to the carcinoma (Adj-CRC). $m R N A$ levels were measured by solution hybridisation RNase protection assay as described in Methods. The values are the relative density of the bands as percentage of the normal adjacent tissue consisting of 12 specimens from six individuals and 12 specimens of tissue from the adenocarcinoma obtained from the same six individuals. Results are mean (SEM). There was a highly significant difference $\left({ }^{\star} p<0.0001\right)$ between the two groups. were removed and $350 \mu$ reagent grade acetone was added; the resulting mixture was vortex-mixed and centrifuged at $3000 \mathrm{~g}$. The supernatants were lyophilized and redissolved in $40 \mathrm{mmol} / \mathrm{l}$ phosphate buffer ( $\mathrm{pH} \mathrm{8}$ ). A linear relation was found between biosynthetic IGF-I and IGF-II and the tissue IGF-I and IGF-II immunoreactivity at multiple concentrations, indicating antigen similarity and absence of interference from proteins and receptors in the extracts. Tissue extracts were kept at $-20^{\circ} \mathrm{C}$ until tissue IGF-I and IGF-II were measured in duplicate in diluted extracts by a noncompetitive time-resolved immunofluorimetric assay as previously described. ${ }^{19}$ IGF-I and IGF-II cross reactivity were less than $0.0002 \%$, and the detection limits were $2.5 \mathrm{ng} / 1$ and 10 ng/l for the IGF-I and IGF-II assays respectively. The intra-assay coefficient of variance for the IGF-I and -II method was less than 5\% and the interassay coefficient less than $10 \%$.

\section{Results}

IGF-II/Man-6-P receptor gene expression in biopsy specimens from healthy individuals was similar to that in biopsy specimens from normal tissue adjacent to adenocarcinoma. However, it was five times higher in the malignant tissue. In malignant polyps, IGF-II expression was about twice as high (fig $1 \mathrm{~A}, \mathrm{~B}$ ). The integrity of the RNA used in the RNase protection assay was assessed by visual inspection of ethidium bromide stained $28 \mathrm{~S}$ and $18 \mathrm{~S}$ ribosomal bands of $10 \mu \mathrm{g}$ aliquots in agarose gel (fig 1C). The two patients with liver metastases had 2.4 and 4 times higher IGF-II/Man6-P receptor gene expression than patients of Dukes' classification A (data not shown).

Expression of IGF-II was about 40 times higher in malignant tissue than in tissue adjacent to the tumour (fig 2).

Expression of IGF-I receptor was 2.5 times higher in the malignant tissue than in tissue adjacent to the tumour (fig 3).

We did not find IGF-I mRNA in healthy or malignant colonic tissue (data not shown).

The amount of IGF-I and IGF-II protein was measured in adenocarcinoma of the colon and in normal adjacent tissue in another group, comprising ten patients. IGF-I was present in equal but small amounts in healthy and malignant tissue (2.3 (1.3) and 2.3 (1.9) ng/g tissue respectively; mean (SD)). IGF-II, however, was twice as abundant in the malignant tissue (31.2 (11.8) $v 16$ (3.1) ng/g tissue; $\mathrm{p}<0.05)$. The levels of tissue IGF-I and -II amounted to about $3-5 \%$ of circulating levels (data not shown).

\section{Discussion}

IGF-II RECEPTOR mRNA IN COLONIC TISSUE

Our results show that colonic tissue from healthy subjects expresses IGF-II/Man-6-P receptor mRNA, suggesting that the receptor is a physiological constituent of healthy colonic tissue in adults.

In our series, all six patients with carcinoma of the colon and the three with carcinomatous polyps had increased expression of IGF-II/Man6-P receptor mRNA compared with the 10 control individuals. IGF-II/Man-6-P receptor has 
previously been shown to be present in malignant colorectal cancer cell lines, ${ }^{9}{ }^{10}$ but this is the first demonstration that it exists in normal colonic tissue and that its expression is higher in colorectal tumour tissue than normal colonic mucosa. Although our numbers are not sufficiently large to allow a correlation of the clinical state and gene expression, it is of interest that the two patients with metastases in the liver had exceptionally high expression compared with other patients with colorectal cancer of a lower grade of invasiveness.

In experimental studies in rats, the IGF-II/ Man-6-P receptor was found to be localised along the whole intestine. It was more densely represented in the distal small intestine and colon than in the jejunum. ${ }^{20}$ The receptor was more abundant in the crypts, a region engaged in proliferation of enterocytes, than in the villus. At 12 hours after resection of the intestine in rats, a significant increase in immunoreactive IGF-II/Man-6-P receptor was found in the villus and crypt regions of the jejunum and ileum, and this increase was maintained for 48 hours. ${ }^{4}$ These observations suggest at first sight that the IGF-II/Man-6-P receptor has a proliferative effect in enterocytes. This, however, seems unlikely as the IGF-II/Man-6-P receptor, unlike the IGF-I receptor, does not possess an intracellular tyrosine kinase activating domain. ${ }^{21}$ Rather, this receptor appears to be similar to the receptor for proteins bearing Man-6-P, a posttranslational modification that functions as a key signal for intracellular targeting of hydrolases, and possibly other proteins, to lysosomes. It is for this reason that the IGF-II/Man-6-P receptor is believed not to subserve a mitogenic function. Indeed, there is overwhelming evidence in the literature indicating that it is the IGF-I receptors that mediate the mitogenic effects of IGF-II. ${ }^{122}$ Although we found the IGF-II/Man-6-P receptor expression to be upgraded in colorectal cancer, we could not prove that it contributes to the development of the tumour. In contrast, in carcinoma of the breast and liver, the IGF-II/Man-6-P receptor has recently been implicated as a putative tumour suppressor gene. In these tissues, loss of heterozygosity for this gene was shown in $30 \%$ and $70 \%$ of tumours respectively. In addition, point mutations were found in the remaining alleles. ${ }^{23-25}$ In contrast, in colorectal cancer we found that the IGF-II receptor message was overexpressed fivefold and the IGF-II message by a factor of 40 .

IGF-I RECEPTOR MRNA IN COLONIC TISSUE Like others, ${ }^{9}$ we found that IGF-I receptor mRNA was also increased in the malignant tissue. Increased amounts of IGF-I receptor at the functional binding protein level have previously been described in several adenocarcinomata. ${ }^{9}$ The IGF-I receptor has been shown also to bind a substantial amount of the IGF-II and to mediate its effects in stimulating proliferation of cells. ${ }^{1022}$ Expression of IGF-I receptor is also upgraded in states of malnutrition, ${ }^{26}$ in tissue repair, ${ }^{27}$ and in numerous malignancies. ${ }^{728}$
IGF-I MRNA AND IGF-I PROTEIN IN COLONIC TISSUE

Like other investigators, we did not find any IGF-I mRNA in healthy or malignant human colonic tissue. ${ }^{3}$ Tricoli et $a l^{4}$ on the other hand did find a 3-5-fold increase in IGF-I mRNA in $20 \%$ of tumours. Although rare in epithelial tumours, increased IGF-I expression is, however, a very common occurrence in ovarian cancers. ${ }^{29}$ We found small amounts of IGF-I protein in the tissues and these were the same in normal adjacent tissue and in the tumour.

\section{IGF-II mRNA AND IGF-II PROTEIN IN COLONIC} TISSUE

IGF-II mRNA levels were elevated in all the malignant colonic tissues investigated by us. Expression of IGF-II mRNA in tissue adjacent to the tumour was normal. These findings are compatible with previous reports. Lambert et $a l^{6}$ analysed 21 human colorectal tumours and found overexpression of IGF-II in six (30\%). Overexpression was moderate (2-15-fold) or marked (200-800-fold). It did not correlate with the site or stage of the tumour nor with the age or sex of the patient. In one of their patients a structural alteration of the IGF-II gene was found. Tricoli et $a l^{4}$ studied IGF-II gene expression in 20 colorectal tumours and found $10-50$-fold increase in 30-40\%. They did find a correlation with Dukes' classification of the tumour. Of special interest was the finding that there was no increased expression of epidermal growth factor or transforming growth factor $\alpha$. This finding emphasises the unique importance of the IGFs in colorectal cancer. The malignant potential of IGF-II in mammary cancer was recently shown in transgenic mice overexpressing IGF- $\mathrm{II}^{30}$ and in the $\mathrm{CaCo} 2$ colon carcinoma cell line. ${ }^{31}$ In human colorectal cancer cell lines it has been shown that IGF-II mRNA expression is associated with production of IGF-II protein. ${ }^{78}$ As no control cell lines were available, it could not be established if the production of IGF-II was increased above normal. We showed a twofold increase in IGF-II protein in malignant tissue. Unfortunately, tissues from different patients were used for the determinations of IGF-II peptide and IGF-II mRNA, but we do not believe that this significantly affects our data. IGF-II peptide was raised by a factor of 2 in ten specimens of carcinoma when compared with control tissue, with a very small standard deviation. It is therefore highly unlikely that had we measured the original six patients we would have obtained significantly different results. On the other hand, the 40 -fold increase in the IGF-II mRNA, which we found in carcinomatous tissue, is in accordance with data obtained by other investigators. ${ }^{46}$ This study does not establish whether the increase in IGF-II protein in the tumour was related to increased local production or increased entrapment by the IGF-I or the IGF-II/Man-6-P receptor or to both these mechanisms. Although the concentrations of IGF-I and -II in both normal and malignant tissue were low compared with circulating levels $(3-5 \%)$, it seems unlikely that the increase in tumour 
IGF-II was due to contamination with serum IGF, as no increase in tumour IGF-I was seen. In the COLO 205 cell line, the addition of IGF-I receptor antibody or antibody to IGF-II significantly depressed growth. It was concluded that IGF-II secreted by these cells could stimulate cell growth in an autocrine fashion through IGF-I receptors. ${ }^{10} 22$

Some colorectal cancers have a genetic instability characterised by alterations within simple repeated nucleotide sequences termed microsatellites. ${ }^{32}$ Such instability is characteristically seen in the hereditary non-polyposis colorectal cancer syndrome, but is also found in $15 \%$ of sporadic colorectal cancers. ${ }^{33}$ In a recent study of colorectal cancer patients with microsatellite instability, $60 \%$ also showed hypermethylation of the IGF-II gene. ${ }^{34}$ This suggests that in this subset of patients, overexpression of the IGF-II gene may not be essential for development of colorectal cancer.

\section{CONCLUSIONS}

This study confirms that colorectal cancer is associated with increased expression of genes belonging to the IGF system. The rise in IGFII/Man-6-P receptor message in colorectal tumour tissue shown here has not previously been reported; however, its relevance to the initiation or maintenance of the tumour remains to be established. We have also shown that, in parallel with the increased expression of IGF-II, IGF-I receptor, and IGF-II/Man-6-P receptor in adenocarcinoma of the colon, there is increased IGF-II protein in the malignant tissues while IGF-I protein remains unchanged. It is suggested that IGF-II may play an important role in the development of this tumour in most patients.

This work was supported by the Miriam Coven-Fish Foundation, by a grant from the Shaare Zedek Hospital, by the Chie Scientist, the Ministry of Health of Israel, the Danish Medical Research Council (grant no 700592), the Novo Foundation, The Nordic Insulin Foundation, the Aage Louis Petersen Foundation, the Institue of Experimental Research, University of Aarhus, Denmark, and the Aarhus University-Novo Nordisk Center for Research in Growth and Regeneration (Danish Medical Research Council; grant no 9600822). We wish to thank the staff of the Institute of Gastroenterology, the Institute of Pathology, and the Department of Surgery of the Shaare Zedek Hospital for help in obtaining the specimens.

1 Vanderhoof JA. Regulatory peptides and intestinal growth. Gastroenterology 1993;104:1205-8.

2 Ulshen MH, Dowling RH, Fuller CR, et al. Enhanced

growth of small bowel in transgenic mice overexpressing growth of small bowel in transgenic mice overexpressing
bovine growth hormone. Gastroenterology 1993;104:97380 .

3 Singh P, Rubin R. Insulinlike growth factors and binding proteins in colon cancer. Gastroenterology 1993;105:121837.

4 Tricoli JV, Rall LB, Karakousis CP, et al. Enhanced levels of insulin-like growth factor mRNA in human colon carcinomas and liposarcomas. Cancer Res 1986;46:6169-73.

5 MacDonald RS, Park JHY, Thornton WH. Insulin, IGF-I and IGF-II receptors in rat small intestine following massive small bowel resection. Dig Dis Sci 1993;38:165869.

6 Lambert S. Vivario J. Boniver J, et al. Abnormal expression and structural modification of the insulin-like growth factor 11 gene in human colorectal tumors. Int $\mathcal{F}$ Cancer 1990;46:405-10.

7 Singh P, Dai B, Yallampali C, et al. Expression of IGF-II and IGF-binding proteins by colon cancer cells in relation to growth response to IGFs. Am f Physiol 1994;267:G608-19.

8 Zrowth response to IGFs. Am f Physiol 1994;267: G608-19. like growth factor (IGF)-II and IGF-I receptor during pro- liferation and differentiation of CaCo-2 human colon arcinoma cells. Cell Growth Differ 1994;5:1085-91.

9 Guo Y-S, Narayan S, Yallampalli C, et al. Characterization of insulinlike growth factor I receptors in human colon cancer. Gastroenterology 1992;102:1101-08.

10 Guo YS, Jin GF, Townsend CM Jr, et al. Insulin-like growth factor II expression in carcinoma in colon cell lines: implications for autocrine actions. I Am Coll Surg 1995;181: 145-54.

11 Garrouste F, Remacle-Bonnet M, Coulouscou JM, et al. Type II insulin-like growth factor receptor in conditioned medium from HT-29 human colon carcinoma cell line. Int medium from HT-29 hum

12 Chomczynski P, Sacchi N. Single step method of RNA isolation by acid guanidium thiocyanate-phenol-chloroform extraction. Anal Biochem 1987;162:156-9.

13 Hernandez ER, Hurwitz A, Vera A, et al. Expression of the genes encoding the insulin-like growth factors and their receptors in the human ovary. F Clin Endocrinol Metab 1992;74:419-25.

14 Lowe WL Jr, Roberts CT Jr, LeRoith D, et al. Insulin-like growth factor II in non-islet cell tumors associated with hypoglycemia:increased levels of messenger ribonucleic acid. 7 Clin Endocrinol Metab 1989;69:1153-9.

15 Ota A, Shen-Orr Z, Roberts CT Jr, et al. TPA-induced neurite formation in a neuroblastoma cell line (SH-SY5Y) is associated with increased IGF-I receptor $\mathrm{mRNA}$ and binding. Mol Brain Res 1989;6:6976.

16 D'Ercole AJ, Stiles AD, Underwood LE. Tissue concentration of somatomedin C: further evidence for multiple sites of synthesis and paracrine or autocrine mechanisms of action. Proc Natl Acad Sci USA 1984;81:935-9.

17 Flyvbjerg A, Thorlacius-Ussing O, Naeraa R, et al. Kidney tissue somatomedin $\mathrm{C}$ and initial renal growth in diabetic and uninephrectomized rats. Diabetologia 1988;31:310-14.

18 Lee W-H, Bowsher RR, Apathy JM, et al. Measurement of insulin-like growth factor II in physiological fluids and tissues. II. Extraction and quantification in rat tissues. Endocrinology 1991;128:815-22.

19 Frystyk J, Dinesen B, Orskov H. Non-competitive time resolved immunofluorimetric assay for determination of human insulin-like growth factor I and II. Growth Regul 1995;5:47-62.

20 Heinz-Erian P, Kessler U, Funk B, et al. Identification of in situ localization of the insulin-like growth factor-II/ mannose-6-phosphate (IGF-II/M6P) receptor in the rat gastrointestinal tract: comparison with the IGF-I receptor. Eastrointestinal tract: comparison

21 Morgan DO, Edman JC, Standring DN, et al. Insulin-like growth factor II receptor as a multifunctional binding protein. Nature 1987;329:301-7.

22 Lamonerie $\mathrm{T}$, Lavialle $\mathrm{C}$, Haddada $\mathrm{H}$, et al. IGF-II autocrine stimulation in tumorigenic clones of a human colon-carcinoma cell line. Int f Cancer 1995;61:587-92.

23 Hankins GR, De Souza AT, Bentley RC, et al. M6P/IGF2 receptor: a candidate breast tumor suppressor gene. Oncogene 1996;12:2003-9.

24 De Souza AT, Hankins GR, Washington MK, et al. $\mathrm{M} 6 \mathrm{P} / \mathrm{IGF} 2 \mathrm{R}$ gene is mutated in human hepatocellular carcinomas with loss of heterozygosity. Nat Genet 1995;11: 447-9.

25 Chappell SA, Walsh T, Walker RA, et al. Loss of heterozygosity at the mannose 6-phosphate insulin-like growth factor 2 receptor gene correlates with poor differentiation in early breast carcinomas. $\mathrm{Br} \mathcal{F}$ Cancer 1997;76:1258-61.

26 Thissen JP, Ketelslegers J-M, Underwood LE. Nutritional regulation of the insulin like growth factors. Endocr Rev 1994;15:80-163.

27 Muironey SE, Haramati A, Werner $\mathrm{H}$, et al. Altered expression of insulin-like growth factor I (IGF-I) and IGF-I receptor genes after unilateral nephrectomy in immature rats. Endocrinology 1992;130:249-56.

28 Werner H, LeRoith D. Insulin-like growth factor I receptor: structure, signal transduction and function. Diabetes Review 1995;3:28-37.

29 Yee D, Morales FR, Hamilton TC, et al. Expression of insulinlike growth factor 1 , its binding proteins and its receptor in ovarian cancer. Cancer Res 1991;51:5107-12.

30 Bates P, Fisher R, Ward A, et al. Mammary cancer in transgenic mice expressing insulin-like growth factor II. $\mathrm{Br} F$ Genic mice expressing in

31 Singh P, Dai B, Yallampalli U, et al. Proliferation and differentiation of a human colon cancer cell line $(\mathrm{CaCo} 2)$ is associated with significant changes in the expression and secretion of insulin-like growth factor II and IGF binding protein 4: role of IGF-II. Endocrinology 1996;137:1764-74.

32 Ionov Y, Peinado MA, Malkhosyan S, et al. Ubiquitous somatic mutations in simple repeated sequences reveal a new mechanism for colonic carcinogenesis. Nature 1993; 363:558-61

33 Thibodeau SN, Bren G, Schaid D. Microsatellite instability in cancer of the proximal colon. Science 1993;260:812-16.

34 Ahuja N, Mohan AL, Li Qu, et al. Association between CpG island methylation and microsatellite instability in colorectal cancer. Cancer Res 1997;57:3370-4. 